\title{
Comparison of the performances of two biotic indices based on the MacroBen database
}

\author{
A. Grémare ${ }^{1, *}$, C. Labrune, E. Vanden Berghe, J. M. Amouroux, G. Bachelet, \\ M. L. Zettler, J. Vanaverbeke, D. Fleischer, L. Bigot, O. Maire, B. Deflandre, \\ J. Craeymeersch, S. Degraer, C. Dounas, G. Duineveld, C. Heip, M. Herrmann, \\ H. Hummel, I. Karakassis, M. Kędra, M. Kendall, P. Kingston, J. Laudien, \\ A. Occhipinti-Ambrogi, E. Rachor, R. Sardá, J. Speybroeck, G. Van Hoey, M. Vincx, \\ P. Whomersley, W. Willems, M. Włodarska-Kowalczuk, A. Zenetos \\ ${ }^{1}$ Université Bordeaux 1, CNRS, UMR 5805 EPOC, Station Marine d'Arcachon, 2 rue du Professeur Jolyet, \\ 33120 Arcachon, France
}

\begin{abstract}
The pan-European MacroBen database was used to compare the AZTI Marine Biotic Index (AMBI) and the Benthic Quality Index $\left(\mathrm{BQI}_{\mathrm{ES}}\right), 2$ biotic indices which rely on 2 distinct assessments of species sensitivity/tolerance (i.e. AMBI EG and BQI E $\left[\mathrm{S}_{50}\right]_{0.05}$ ) and which up to now have only been compared on restricted data sets. A total of 12409 stations were selected from the database. This subset (indicator database) was later divided into 4 marine and 1 estuarine subareas. We computed $\mathrm{E}\left(\mathrm{S}_{50}\right)_{0.05}$ in 643 taxa, which accounted for $91.8 \%$ of the total abundances in the whole marine indicator database. AMBI EG and $\mathrm{E}\left(\mathrm{S}_{50}\right)_{0.05}$ correlated poorly. Marked heterogeneities in $\mathrm{E}\left(\mathrm{S}_{50}\right)_{0.05}$ between the marine and estuarine North Sea and between the 4 marine subareas suggest that sensitivity/tolerance levels vary among geographical areas. High values of AMBI were always associated with low values of $B \mathrm{BI}_{\mathrm{ES}}$, which underlines the coherence of these 2 indices in identifying stations with a bad ecological status (ES). Conversely, low values of AMBI were sometimes associated with low values of BQI $\mathrm{ES}_{\mathrm{ES}}$ resulting in the attribution of a good ES by AMBI and a bad ES by BQI $\mathrm{ES}_{\mathrm{ES}}$. This was caused by the dominance of species classified as sensitive by AMBI and tolerant by BQI $\mathrm{E}_{\mathrm{ES}}$. Some of these species are known to be sensitive to natural disturbance, which highlights the tendency of $\mathrm{BQI}_{\mathrm{ES}}$ to automatically classify dominant species as tolerant. Both indices thus present weaknesses in their way of assessing sensitivity/tolerance levels (i.e. existence of a single sensitivity/tolerance list for $\mathrm{AMBI}$ and the tight relationship between dominance and tolerance for $\mathrm{BQI}_{\mathrm{ES}}$ ). Future studies should focus on the (1) clarification of the sensitivity/tolerance levels of the species identified as problematic, and (2) assessment of the relationships between AMBI EG and $\mathrm{E}\left(\mathrm{S}_{50}\right)_{0.05}$ within and between combinations of geographical areas and habitats.
\end{abstract}

KEY WORDS: AZTI Marine Biotic Index - Benthic Quality Index · Macrozoobenthos - Water framework directive

Resale or republication not permitted without written consent of the publisher

\section{INTRODUCTION}

The European Water Framework Directive (WFD) establishes a basis for the protection of ground, continental, transitional and coastal waters. It aims at achieving a good ecological status (ES) for all European water bodies by 2015. The first step consists of assessing the current ES of these water bodies, which is based on a large variety of hydromorphological, physicochemical and biological parameters. In order to unravel natural and man-induced changes, ES values are derived from ecological quality ratios (EQR), which correspond to the ratio of the value of the considered parameter at each sampled station divided by the value of the same parameter at a reference (i.e. nonimpacted) station (Wallin et al. 2003). 
Macrozoobenthos is one of the biological compartments considered by the WFD (Borja et al. 2004a, Borja 2005) and a large variety of biotic indices use its composition to infer ES (Grall \& Glémarec 1997, Borja et al. 2000, Gomez Gesteira \& Dauvin 2000, Rosenberg et al. 2004). In spite of their diversity, most of these indices are based on the same paradigm: disturbances are generating secondary successions during which tolerant species are at first dominant and then progressively replaced by sensitive species (Pearson \& Rosenberg 1978). There is, thus, more need for testing and unifying the existing benthic biotic indices than for producing new ones (Diaz et al. 2004). Two of the main indices introduced in view of the implementation of the WFD are (1) the AZTI Marine Biotic Index (AMBI; Borja et al. 2000), and (2) the Benthic Quality Index (BQI; Rosenberg et al. 2004). Although these 2 indices rely on the same concept, they differ in (1) their ways of assessing species sensitivity/tolerance levels, (2) the consideration of species richness, and (3) the procedures used to convert computed indices of ES.

In AMBI, sensitivity/tolerance levels are assessed based on the compilation of expert knowledge and its translation into ecological groups (AMBI EG). This results in a single sensitivity/tolerance per species that is used for all data sets irrespective of geographic location (Borja et al. 2000, Borja et al. 2003, Salas et al. 2004, Muxika et al. 2005). Conversely, for BQI, Rosenberg et al. (2004) assume that species sensitivity/tolerance levels vary according to geographical location. The assessment of sensitivity/tolerance within BQI is based on the concept of $\mathrm{E}\left(\mathrm{S}_{50}\right)_{0.05}$ (see 'Data and methods' for definition) (Rosenberg et al. 2004). The availability of $\mathrm{E}\left(\mathrm{S}_{50}\right)_{0.05}$ constitutes a severe limitation to the computation of BQI, which is either restricted to large data sets (Rosenberg et al. 2004, Labrune et al. 2006, Dauvin et al. 2007, Zettler et al. 2007) or to areas where a list of $\mathrm{E}\left(\mathrm{S}_{50}\right)_{0.05}$ is available (Reiss \& Kröncke 2005).

The computation of AMBI is based on the sole sensitivity/tolerance concept (Borja et al. 2000), which makes it largely sampling effort-independent (Fleischer et al. 2007, Muxika et al. 2007b). Conversely, BQI also takes into account species richness $(S)$ through a $\log (S+1)$ term (Rosenberg et al. 2004), which makes it sampling effort-dependent when computed on lumped data (Fleischer et al. 2007) and/or on individual samples collected with different gears. This constitutes another restriction to its use since large databases are (1) often constituted of several surveys with different sampling strategies (see Table 1 for the present study), and (2) often comprised of a significant proportion of lumped data (i.e. $96.3 \%$ of all stations during the present study). Fleischer et al. (2007) proposed to overcome this difficulty by replacing $\log (S+1)$ by $\log \left(E\left[S_{50}\right]+1\right)$ and proved that the so-modified BQI (i.e. $\mathrm{BQI}_{\mathrm{ES}}$ ) is indepen- dent of sampling effort and correlates tightly with BQI.

AMBI uses a single scale to infer ES (Borja et al. 2004a), whereas BQI assumes that for each habitat the station with the highest BQI constitutes a valid reference for the computation of EQR. The stations with an EQR higher than 0.6 are then considered to at least be in a good ES (Rosenberg et al. 2004).

Multivariate AMBI (M-AMBI) was recently introduced as a refinement of AMBI (Borja et al. 2004b, Borja et al. 2007, Muxika et al. 2007a). Its computation involves a factorial correspondence analysis (FCA) based on AMBI, species richness and the ShannonWiener diversity index, $H^{\prime}$. FCAs are carried out for each habitat and 2 bad and good reference stations are included. The coordinates of the projection of the stations along the axis linking the bad and good reference stations in the first plane of the FCA constitute EQR, which are transformed into ES using an appropriate conversion scale (Wallin et al. 2003). M-AMBI is much more similar to BQI than AMBI since it accounts for species richness and uses several scales to infer ES. BQI and M-AMBI, however, still largely differ in their assessments of species sensitivity/tolerance.

Both AMBI and BQI were initially proposed and tested based on individual data sets (Borja et al. 2000, Rosenberg et al. 2004). AMBI has, since then, been tested on a large variety of other (but still mostly individual) data sets (Borja et al. 2000, 2003, Salas et al. 2004, Marin-Guirao et al. 2005, Muniz et al. 2005, Muxika et al. 2005, Bigot et al. 2008, Blanchet et al. 2008), BQI has been tested on a much smaller number of datasets due to the difficulty in computing $\mathrm{E}\left(\mathrm{S}_{50}\right)_{0.05}$. AMBI and BQI have recently been compared in the North Sea (Reiss \& Kröncke 2005), the Gulf of Lions (Labrune et al. 2006), the Seine estuary (Dauvin et al. 2007) and the Baltic Sea (Zettler et al. 2007). All comparisons have shown major discrepancies but have largely ignored their potential causes. The adequacy of the use of a single sensitivity/tolerance list by AMBI as opposed to BQI is, for example, yet to be tested partly due to the lack of any comprehensive database at the pan-European level. The Network of Excellence Marine Biodiversity and Ecosystem Functioning (MarBEF) has recently filled this gap for soft-bottom macrozoobenthos by creating the MacroBen database. The aim of the present study is to use this new tool to (1) promote the use of $\mathrm{BQI}_{\mathrm{ES}}$ by providing lists of $\mathrm{E}\left(\mathrm{S}_{50}\right)_{0.05}$ both at the pan-European level and within distinct geographic subareas, (2) compare AMBI EG and $\mathrm{E}\left(\mathrm{S}_{50}\right)_{0.05}$, (3) assess the validity of the use of a single list of sensitivity/tolerance levels by comparing $\mathrm{E}\left(\mathrm{S}_{50}\right)_{0.05}$ between subareas, (4) assess the relationships between $\mathrm{AMBI}$ and $\mathrm{BQI}_{\mathrm{ES}}$ and (5) compare the ES assessments derived from $\mathrm{AMBI}$ and $\mathrm{BQI} \mathrm{ES}_{\mathrm{ES}}$. 


\section{DATA AND METHODS}

MacroBen database. The main characteristics of MacroBen are described in Vanden Berghe et al. (2009, this Theme Section) and will not be repeated here. The filtering procedure used during the present study consisted of selecting (1) quantitative data, (2) adult animal taxa, (3) organisms identified to the species level, (4) non-colonial organisms and (5) samples collected after 1980. Baltic Sea samples were excluded because an extensive comparison between AMBI and BQI has recently been carried out in this area (Zettler et al. 2007), and Black Sea samples were excluded because they were too few. The data set was further reduced by considering only the most recent sampling date for each station. This reduced indicator database was com- posed of 29 individual data sets and contained a total of 12409 stations (Fig. 1, Table 1). It was later divided into 4 subareas based on the Large Marine Ecosystem classification (www.edc.uri.edu/lme/intro.htm), namely: (1) the Celtic-Biscay Shelf (115 stations), (2) the Mediterranean (426 stations), (3) the North Sea (11 664 stations), and (4) the Norwegian and Barents Seas (204 stations). Because of the importance of the ni data set (10 251 stations), North Sea data were divided in an estuarine (i.e. ni) and a marine (1413 stations) data set. The ranges of $\mathrm{E}\left(\mathrm{S}_{50}\right)$ (see 'Data and methods Computation of $\mathrm{AMBI}$ and $\mathrm{BQI}_{\mathrm{ES}}$ ' for definitions) in each marine subarea were: 1.95 to $33.53,2.86$ to 34.61 , 1.35 to 39.59 and 1.00 to 33.19 in the Celtic-Biscay Shelf, the Norwegian and Barents Seas, the Mediterranean and the marine North Sea, respectively.

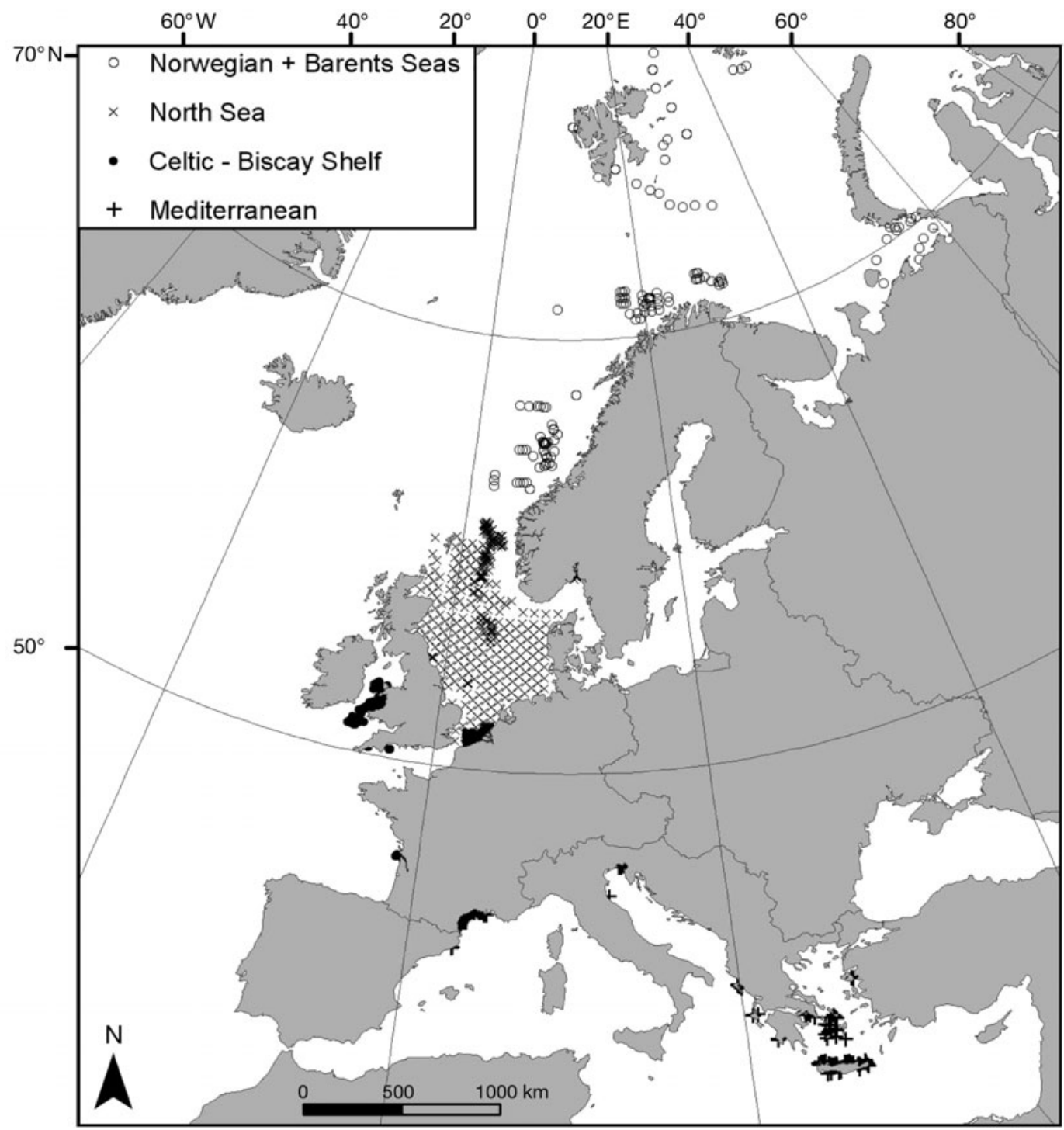

Fig. 1. Location of the stations in the indicator database delimiting of the 4 geographical marine subareas considered during the present study 
Table 1. Composition of the indicator data set with information regarding the location and the number of stations in the 4 subareas and in each individual data set. Depth range, sampling gear, sample replication and total sampled area is also provided for each individual data set

\begin{tabular}{|c|c|c|c|c|c|c|}
\hline $\begin{array}{l}\text { Data set } \\
\text { and subarea }\end{array}$ & Location & $\begin{array}{l}\text { Depth } \\
\text { range }(\mathrm{m})\end{array}$ & $\begin{array}{l}\text { No. } \\
\text { stations }\end{array}$ & Sample gear & $\begin{array}{l}\text { No. } \\
\text { replicates }\end{array}$ & $\begin{array}{l}\text { Total sampled } \\
\text { area }\left(\mathrm{m}^{2}\right)\end{array}$ \\
\hline \multicolumn{7}{|c|}{ Norwegian and Barents Seas } \\
\hline ar & Svalbard & $75-335$ & 22 & Box corer & 1 & 0.1 \\
\hline hs & Hornsund & $25-203$ & 34 & Van Veen grab & 1 & 0.1 \\
\hline ko & Kongsfjorden/Spitsbergen & $5-30$ & 6 & Box corer & 1 & - \\
\hline o2 & Northern Barents Sea & - & 10 & Van Veen grab & $4-5$ & $0.4-0.5$ \\
\hline $\mathrm{o} 4_{\mathrm{NB}}$ & Norwegian Sea & $71-1520$ & 55 & Van Veen grab & $1-5$ & $0.1-0.5$ \\
\hline o6 & Finmark & $160-374$ & 53 & Van Veen grab & 5 & 0.5 \\
\hline 07 & Pechoran Sea & $7-207$ & 15 & Van Veen grab & $3-5$ & $0.3-0.5$ \\
\hline o8 & Franz Josef Land & $52-312$ & 9 & Van Veen grab & 5 & 0.5 \\
\hline \multicolumn{7}{|l|}{ North Sea } \\
\hline ni & Dutch Delta area & $0-57$ & 10251 & - & 1 & - \\
\hline$n p_{\mathrm{NS}}$ & North Sea & $35-70$ & 20 & - & 1 & 0.1 \\
\hline ns & Belgian part of the North Sea & $0-150$ & 231 & Van Veen grab & - & - \\
\hline o3 & Statfjord, Oseberg, Ekosfisk & $65-91$ & 30 & Van Veen grab & $1-5$ & $0.1-0.5$ \\
\hline $\mathrm{o} 4_{\mathrm{NS}}$ & Norwegian coast & $71-1520$ & 128 & Van Veen grab & - & - \\
\hline of & Oslo Fjord & $19-356$ & 57 & Van Veen grab & 1 & 0.1 \\
\hline ug & North Sea & $0-40$ & 947 & - & 3 & $0.09-0.27$ \\
\hline \multicolumn{7}{|c|}{ Celtic-Biscay Shelf } \\
\hline$n p_{\mathrm{CS}}$ & English Channel, Irish Sea & $50-96$ & 20 & - & 1 & 0.1 \\
\hline o5 & Southern Irish Sea & $7-130$ & 51 & Van Veen grab & 1 & - \\
\hline $\mathrm{pl}$ & Plymouth Sound & 15 & 44 & SCUBA diving & 1 & 0.008 \\
\hline \multicolumn{7}{|l|}{ Mediterranean } \\
\hline bl & Bay of Blanes & - & 2 & Van Veen grab & 5 & 0.3 \\
\hline do & Continental Cretan Shelf & $10-60$ & 56 & Smith McIntyre grab & 1 & 0.1 \\
\hline gr & Gulf of Lions & $10-50$ & 92 & Van Veen grab & $2-4$ & $0.2-0.4$ \\
\hline $\mathrm{ka}$ & Cretan Shelf & $10-190$ & 199 & - & - & 0.1 \\
\hline $\operatorname{lm}$ & Gulf of Trieste, Adriatic & $4-25$ & 28 & Van Veen grab & 1 & - \\
\hline M0 & Gialova Lagoon, Ionian Sea & - & 7 & Van Veen grab & 5 & 0.25 \\
\hline M2 & Gulf of Geras, Aegean Sea & - & 9 & Ponar grab & 1 & 0.045 \\
\hline M3 & Saronikos Gulf & - & 6 & Ponar grab & $2-5$ & $0.1-0.25$ \\
\hline M7 & Kerkyra, Ionian Sea & - & 12 & Van Veen grab & 1 & 0.2 \\
\hline M8 & Kyklades, Aegean Sea & - & 14 & Smith McIntyre grab & $3-5$ & $0.3-0.5$ \\
\hline $\mathrm{OC}$ & Northern Adriatic & 12 & 1 & Van Veen grab & 1 & 0.06 \\
\hline
\end{tabular}

Computation of AMBI and $\mathbf{B Q I} \mathbf{E S}_{\mathrm{ES}}$. AMBI was computed as:

$$
\begin{aligned}
\mathrm{AMBI}= & {[(0 \times \% \mathrm{GI})+(1.5 \times \% \text { GII })+(3 \times \% \text { GIII })+(4.5 \times} \\
& \% \text { GIV })+(6 \times \% \text { GV })] / 100
\end{aligned}
$$

where \%GI is the relative abundance of disturbancesensitive species, \%GII is the relative abundance of disturbance-indifferent species, \%GIII is the relative abundance of disturbance-tolerant species, \%GIV is the relative abundance of second-order opportunistic species and \%GV is the relative abundance of firstorder opportunistic species (Borja et al. 2000). AMBI was computed as recommended by Borja \& Muxika (2005) using a specific function implemented in MacroBen and based on the species reference list available at www.azti.es in July 2006. We used a single fixed scale to infer ES from AMBI (Borja et al. 2004a).

$\mathrm{E}\left(\mathrm{S}_{50}\right)_{0.05}$ is defined as the $\mathrm{E}\left(\mathrm{S}_{50}\right)$ (Hurlbert 1971) corresponding to the 5 lowest percentiles of the total abundance of the considered species within the studied area (Rosenberg et al. 2004). $\mathrm{E}\left(\mathrm{S}_{50}\right)_{0.05}$ values were computed for the whole marine indicator data set and each subarea.

$\mathrm{BQI}_{\mathrm{ES}}$ was then computed as:

$$
\mathrm{BQI}_{\mathrm{ES}}=\left\{\sum_{i=1}^{s}\left[\frac{A_{i}}{A_{\mathrm{Tot}}} \times \mathrm{E}\left(\mathrm{S}_{50}\right)_{0.05 i}\right]\right\} \times \log _{10}\left[\mathrm{E}\left(\mathrm{S}_{50}\right)+1\right]
$$

where $A_{i}$ is the abundance of the $i$ th species at the considered station, $\mathrm{E}\left(\mathrm{S}_{50}\right)_{0.05 i}$ is the $\mathrm{E}\left(\mathrm{S}_{50}\right)_{0.05}$ of species $i$ in the considered subarea, $A_{\text {Tot }}$ is the total abundance of the individuals belonging to the species for which $\mathrm{E}\left(\mathrm{S}_{50}\right)_{0.05}$ can be computed and $\mathrm{E}\left(\mathrm{S}_{50}\right)$ is the expected number of species in a sample of 50 individuals taken at the considered station (Fleischer et al. 2007). $\mathrm{E}\left(\mathrm{S}_{50}\right)_{0.05}$ and $\mathrm{BQI}_{\mathrm{ES}}$ were computed on lumped data using a specific function implemented in MacroBen. $\mathrm{E}\left(\mathrm{S}_{50}\right)_{0.05}$ values were not computed for species present at less than 20 stations. We used several conversion 
scales to infer ES from BQI $\mathrm{ES}_{\mathrm{ES}}$. Homogeneous habitats were defined based on multidimensional scaling and cluster analyses of macrozoobenthos composition carried out on the whole subarea data set (Celtic-Biscay Shelf and Norwegian and Barents Seas) or on each major individual data set (i.e. ka, gr and do, see Table 1) in the Mediterranean and the North Sea. The highest value of $\mathrm{BQI}_{\mathrm{ES}}$ in each homogeneous habitat was used to compute an EQR. Each scale was then obtained by dividing these maximal values into 5 equal classes (Rosenberg et al. 2004).

\section{RESULTS}

\section{Computation of $\mathrm{E}\left(\mathrm{S}_{50}\right)_{0.05}$ between subareas and with AMBI EG}

We computed the $\mathrm{E}\left(\mathrm{S}_{50}\right)_{0.05}$ of 76 species in the Celtic-Biscay Shelf, 246 in the Mediterranean, 165 in the Norwegian and Barents Seas, 337 in the marine North Sea and 158 in the estuarine North Sea. The corresponding lists are available at: www.marbef. org/documents/data/theme1/es50_005.xls. The proportions of species and/or individuals - which are attributed sensitivity/tolerance levels, essential for a sound assessment of ES using either AMBI and $\mathrm{BQI}_{\mathrm{ES}}$ - with an $\mathrm{E}\left(\mathrm{S}_{50}\right)_{0.05}$ were between 16.0 (Celtic-Biscay Shelf) and $54.7 \%$ (estuarine North Sea), much lower than for AMBI EG (91.8 and 92.4\%, respectively) (Fig. 2A). Differences between the 2 indices were lower when considering the number of individuals. The proportions of individuals with an $\mathrm{E}\left(\mathrm{S}_{50}\right)_{0.05}$ were between $69.9 \%$ (Norwegian and Barents Seas) and 99.8\% (estuarine North Sea), which were still lower than for AMBI EG (88.7 and 99.9\%, respectively) (Fig. 2B). When considering the marine indicator data set as a whole, 643 species $(46.7 \%)$ corresponding to $91.8 \%$ of individuals were attributed an $\mathrm{E}\left(\mathrm{S}_{50}\right)_{0.05}$ (versus $97.1 \%$ of individuals for AMBI EG).

Dipolydora quadrilobata, Microdeutopus gryllotalpa, Boccardiella ligerica, Streblospio shrubsolii, Spio armata, Corophium volutator and Hydrobia ulvae were the most dominant (rank < 97) species in the marine indicator data set lacking an $\mathrm{E}\left(\mathrm{S}_{50}\right)_{0.05}$ (Table 2). Dacrydium vitreum, Potamides conicus, Eudorellopsis deformis, Micronephthys maryae and Crenella decussata were the most dominant (rank < 141) species in the marine indicator data set lacking an AMBI EG (Table 2).

A

B
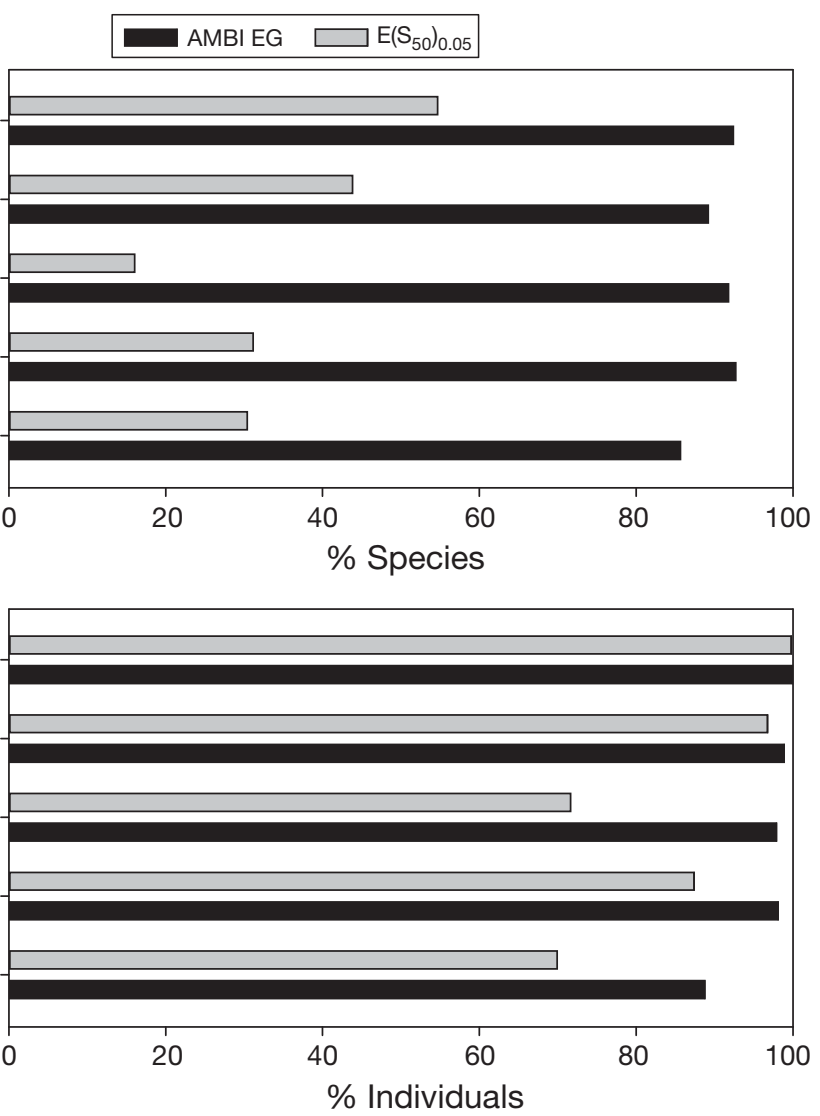

$\%$ Individuals an AMBI EG or an $\mathrm{E}\left(\mathrm{S}_{50}\right)_{0.05}$ value in the different subareas

Table 2. Most dominant (ranks based on decreasing abundances) species in the whole marine indicator data set which are still lacking an $\mathrm{E}\left(\mathrm{S}_{50}\right)_{0.05}$ and/or an AMBI EG value

\begin{tabular}{|lccc|}
\hline Species & Rank & $\mathrm{E}_{\left(\mathrm{S}_{50}\right)_{0.05}}$ & $\mathrm{AMBI} \mathrm{EG}$ \\
\hline Dipolydora quadrilobata & 16 & - & $\mathrm{IV}$ \\
Microdeutopus gryllotalpa & 33 & - & $\mathrm{III}$ \\
Boccardiella ligerica & 39 & - & $\mathrm{III}$ \\
Streblospio shrubsolii & 43 & - & $\mathrm{III}$ \\
Spio armata & 56 & - & $\mathrm{III}$ \\
Dacrydium vitreum & 67 & 9.82 & - \\
Corophium volutator & 91 & - & $\mathrm{III}$ \\
Hydrobia ulvae & 96 & - & $\mathrm{III}$ \\
Langerhansia heterochaeta & 102 & - & $\mathrm{II}$ \\
Potamides conicus & 122 & - & - \\
Eudorellopsis deformis & 127 & 12.27 & - \\
Micronephthys maryae & 139 & 13.25 & - \\
Crenella decussata & 140 & - & - \\
Aricidea fragilis mediterranea & 163 & - & $\mathrm{I}$ \\
Microphthalmus similis & 167 & - & $\mathrm{II}$ \\
Malacoceros fuliginosus & 169 & - & $\mathrm{V}$ \\
Ophelina abranchiata & 173 & 17.88 & - \\
Pectinaria belgica & 179 & - & $\mathrm{I}$ \\
Dendrodoa grossularia & 180 & - & $\mathrm{I}$ \\
Axinopsida orbiculata & 184 & - & - \\
Octobranchus floriceps & 195 & 23.43 & - \\
\hline
\end{tabular}


$\mathrm{E}\left(\mathrm{S}_{50}\right)_{0.05}$ values were between 1.00 and $10.48,1.96$ and $24.14,5.64$ and $25.77,1.35$ and 28.36, and 2.86 and 27.85 in the estuarine North Sea, marine North Sea, Celtic-Biscay Shelf, Mediterranean and Norwegian and Barents Seas, respectively. When considering the whole marine indicator data set, there was a significant

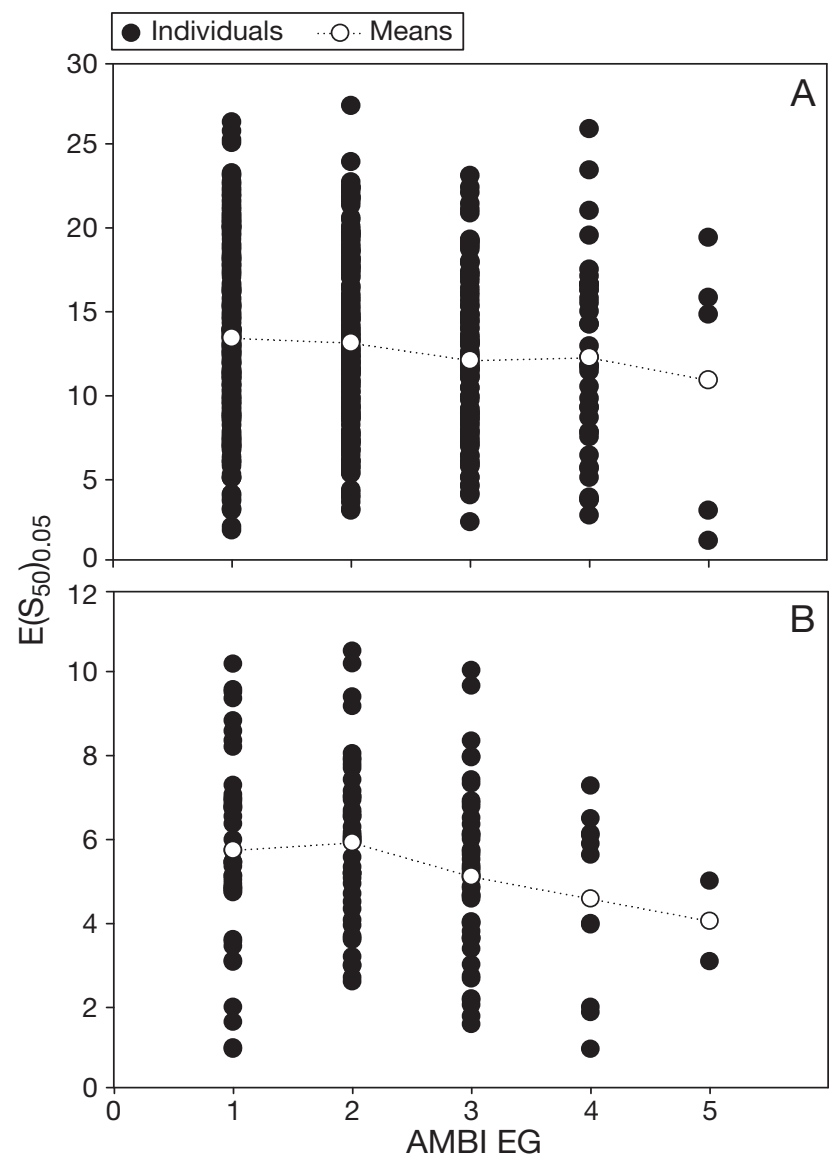

Fig. 3. Relationship between AMBI EG and $E\left(\mathrm{~S}_{50}\right)_{0.05}$ in the $(\mathrm{A})$ whole marine indicator data set and (B) estuarine North Sea. Closed symbols refer to individual stations and open symbols to the mean value of $\mathrm{E}\left(\mathrm{S}_{50}\right)_{0.05}$ for each AMBI EG negative correlation between AMBI EG and $\mathrm{E}\left(\mathrm{S}_{50}\right)_{0.05}$ (Fig. 3, Table 3), even though the explicative power of the corresponding linear regression model was low. There were significant (but still weak) negative correlations between these 2 parameters in the marine and estuarine North Sea and in the Norwegian and Barents

Table 3. Main characteristics of the simple linear regression models linking AMBI EG and $\mathrm{E}\left(\mathrm{S}_{50}\right)_{0.05}$ in the whole marine data set and within each subarea. Significant $(p<0.05)$ negative correlations are in bold

\begin{tabular}{|lccccc|}
\hline Subarea & $\mathrm{N}$ & $\mathrm{r}$ & $\mathrm{p}$ & Intercept & Slope \\
\hline Marine indicator & 669 & -0.150 & $<0.0001$ & 14.86 & -1.32 \\
$\quad$ data set & & & & & \\
Celtic-Biscay Shelf & 75 & 0.022 & 0.848 & - & - \\
Mediterranean & 240 & 0.037 & 0.572 & - & - \\
Marine North Sea & 95 & -0.324 & 0.001 & 17.82 & -1.64 \\
$\begin{array}{l}\text { Norwegian and } \\
\quad \text { Barents Seas }\end{array}$ & 143 & -0.217 & 0.009 & 19.75 & -1.38 \\
$\begin{array}{l}\text { Estuarine North } \\
\quad 152\end{array}$ & -0.185 & 0.023 & 6.350 & -0.385 \\
$\quad$ & & & & & \\
\hline
\end{tabular}

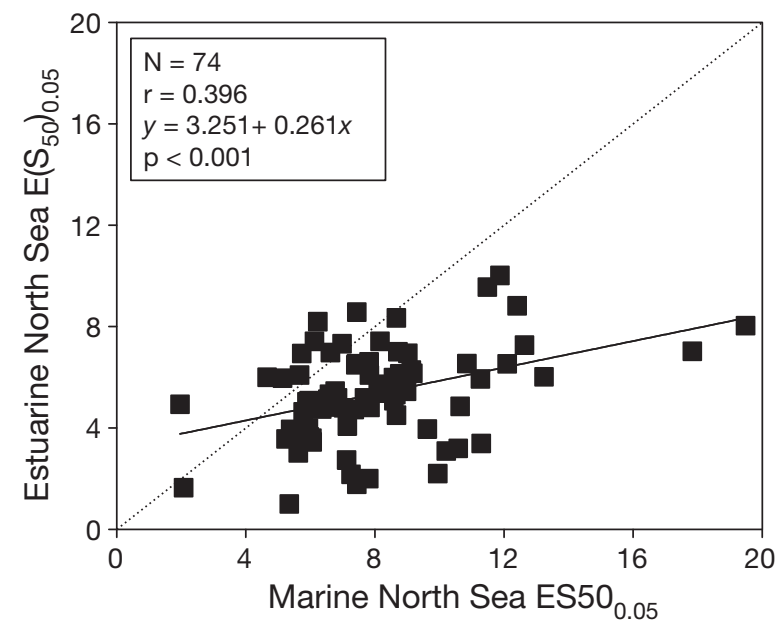

Fig. 4. Relationship between $\mathrm{E}\left(\mathrm{S}_{50}\right)_{0.05}$ in the marine and estuarine North Sea. Solid line: linear regression; dotted line: $\mathrm{y}=\mathrm{x}$

Table 4. $\mathrm{E}\left(\mathrm{S}_{50}\right)_{0.05}$ of the 11 species for which they could be computed in all 4 marine subareas. VC: variation coefficient computed for the 4 marine subareas

\begin{tabular}{|c|c|c|c|c|c|c|}
\hline Species & $\begin{array}{c}\text { Celtic- } \\
\text { Biscay Shelf }\end{array}$ & Mediterranean & $\begin{array}{l}\text { Marine } \\
\text { North Sea }\end{array}$ & $\begin{array}{c}\text { Norwegian and } \\
\text { Barents Seas }\end{array}$ & $\begin{array}{c}\text { Marine indicator } \\
\text { data set }\end{array}$ & $\mathrm{VC}(\%)$ \\
\hline Heteromastus filiformis & 5.64 & 2.56 & 7.81 & 16.81 & 16.81 & 74.6 \\
\hline Goniada maculata & 9.21 & 18.98 & 11.16 & 22.34 & 22.34 & 40.5 \\
\hline Scoloplos armiger & 9.34 & 18.51 & 7.26 & 11.24 & 11.24 & 42.2 \\
\hline Myriochele oculata & 11.90 & 7.16 & 6.95 & 13.99 & 13.99 & 35.1 \\
\hline Owenia fusiformis & 10.36 & 6.18 & 13.24 & 9.82 & 9.82 & 29.3 \\
\hline Aricidea catherinae & 17.49 & 18.56 & 17.10 & 15.71 & 15.71 & 6.8 \\
\hline Paradoneis lyra & 17.54 & 18.93 & 18.28 & 19.43 & 19.43 & 4.4 \\
\hline Scalibregma inflatum & 9.34 & 21.78 & 11.88 & 9.94 & 9.94 & 43.8 \\
\hline Prionospio cirrifera & 17.99 & 10.55 & 13.28 & 12.01 & 12.01 & 23.9 \\
\hline Spiophanes kroyeri & 17.50 & 18.13 & 12.06 & 16.09 & 16.09 & 17.1 \\
\hline Terebellides stroemii & 16.73 & 19.46 & 17.81 & 9.82 & 9.82 & 26.6 \\
\hline
\end{tabular}


Seas (Table 3). This correlation was not significant in the Mediterranean or in the Celtic-Biscay Shelf, where AMBI was initially developed.

There was a weak but significant positive correlation between $E\left(\mathrm{~S}_{50}\right)_{0.05}$ in the marine and estuarine North Sea (Fig. 4). However, $\mathrm{E}\left(\mathrm{S}_{50}\right)_{0.05}$ tended to be lower in the estuarine than in marine North Sea (Wilcoxon signed-rank test, $\mathrm{p}<0.001)$. There were only 11 species for which we were able to compute $\mathrm{E}\left(\mathrm{S}_{50}\right)_{0.05}$ in all
4 marine subareas (Table 4). Overall there were marked changes in $\mathrm{E}\left(\mathrm{S}_{50}\right)_{0.05}$ between subareas as indicated by variation coefficients between $4.4 \%$ (Paradoneis lyra) and $74.6 \%$ (Heteromastus filiformis). When comparing the $\mathrm{E}\left(\mathrm{S}_{50}\right)_{0.05}$ of species occurring in any combination of 2 subareas, we found significant positive correlations between the marine North Sea and both the Celtic-Biscay Shelf and the Norwegian and Barents Seas (Fig. 5). Here again, the explicative pow-
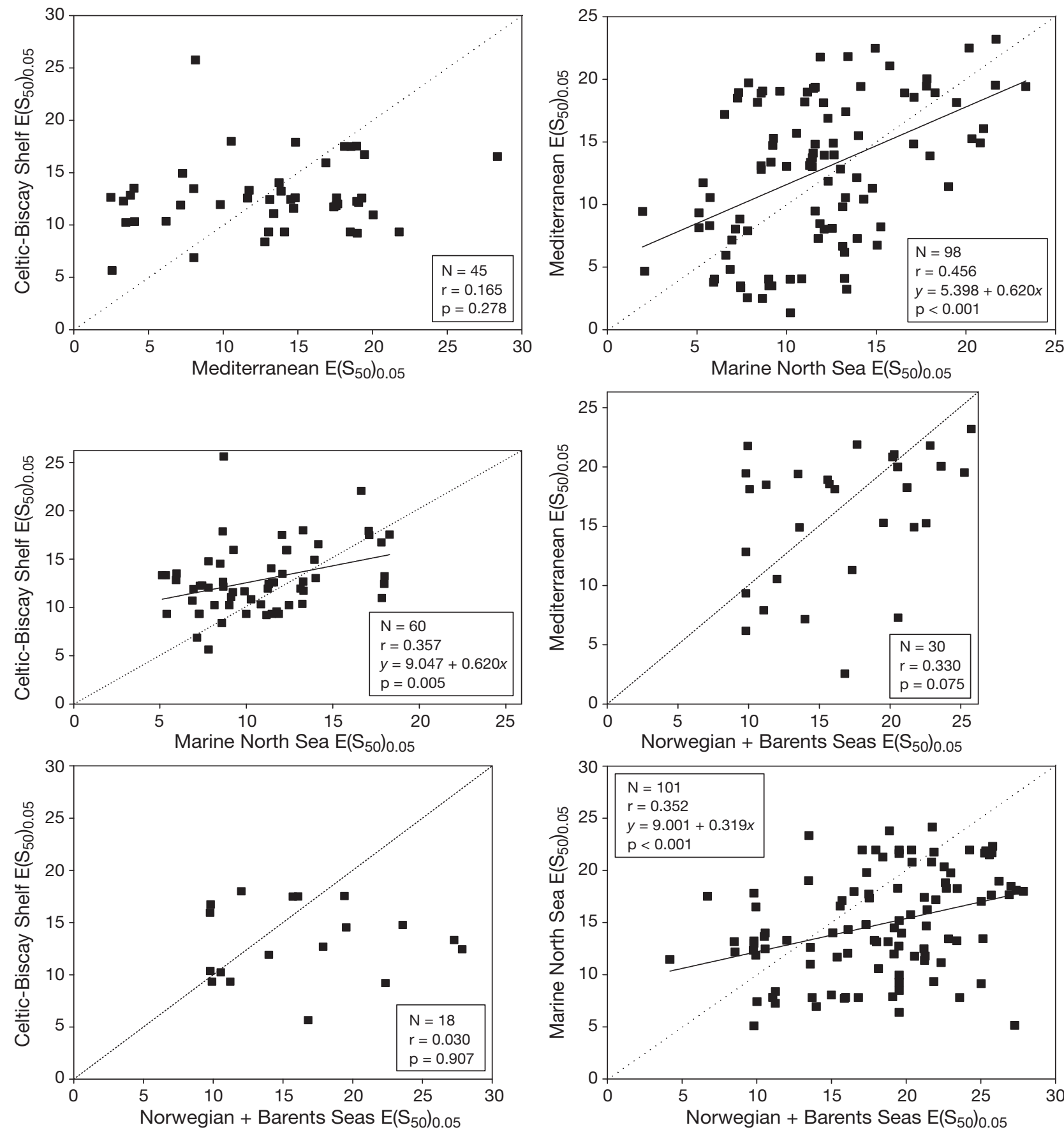

Fig. 5. Relationships between $\mathrm{E}\left(\mathrm{S}_{50}\right)_{0.05}$ in the 4 marine subareas. Solid line: linear regression, dotted line: $y=x$ 
Table 5. Significance of the Wilcoxon signed-rank tests used to compare the $\mathrm{E}\left(\mathrm{S}_{50}\right)_{0.05}$ computed within different marine subareas. $\mathrm{N}$ : number of species for which $\mathrm{E}\left(\mathrm{S}_{50}\right)_{0.05}$ could be computed in the 2 considered subareas. Significant $(p<0.05)$ differences are in bold

\begin{tabular}{|c|c|c|c|c|c|c|}
\hline & \multicolumn{2}{|c|}{$\begin{array}{c}\text { Celtic- } \\
\text { Biscay Shelf }\end{array}$} & \multicolumn{2}{|c|}{$\begin{array}{l}\text { Mediter- } \\
\text { ranean }\end{array}$} & \multicolumn{2}{|c|}{$\begin{array}{c}\text { Marine } \\
\text { North Sea }\end{array}$} \\
\hline & $\mathrm{p}$ & $\mathrm{N}$ & $\mathrm{p}$ & $\mathrm{N}$ & $\mathrm{p}$ & $\mathrm{N}$ \\
\hline Celtic-Biscay Shelf & - & & & & & \\
\hline Mediterranean & 0.505 & 45 & - & & & \\
\hline Marine North Sea & $<0.001$ & 60 & 0.184 & 98 & - & \\
\hline $\begin{array}{l}\text { Norwegian and } \\
\text { Barents Seas }\end{array}$ & 0.099 & 18 & 0.508 & 30 & $<0.001$ & 101 \\
\hline
\end{tabular}

Table 6. Main characteristics of the simple linear regression models linking $\mathrm{AMBI}$ and $\mathrm{BQI}_{\mathrm{ES}}$ in the different subareas and individual data sets. Significant $(p<0.05)$ negative correlations are in bold

\begin{tabular}{|c|c|c|c|c|c|}
\hline Data set & $\mathrm{N}$ & $r$ & $\mathrm{p}$ & Intercept & Slope \\
\hline $\begin{array}{l}\text { Norwegian and } \\
\text { Barents Seas }\end{array}$ & 204 & & $<0.001$ & 31.267 & -5.991 \\
\hline ar & 22 & -0.308 & 0.164 & - & - \\
\hline hs & 31 & -0.911 & $<0.001$ & 9.557 & -1.397 \\
\hline ko & 6 & -0.667 & 0.148 & - & - \\
\hline o2 & 10 & -0.366 & 0.298 & - & - \\
\hline $\mathrm{o} 4_{\mathrm{NB}}$ & 57 & -0.745 & $<0.001$ & 40.930 & -8.476 \\
\hline o6 & 54 & 0.220 & 0.110 & - & - \\
\hline 07 & 15 & -0.083 & 0.769 & - & - \\
\hline o8 & 9 & 0.355 & 0.349 & - & - \\
\hline $\begin{array}{l}\text { Marine } \\
\text { North Sea }\end{array}$ & 850 & 0.013 & 0.715 & - & - \\
\hline$n p_{\mathrm{NS}}$ & 14 & -0.530 & 0.051 & - & - \\
\hline ns & 224 & 0.315 & $<0.001$ & 10.606 & 1.812 \\
\hline o3 & 30 & -0.913 & $<0.001$ & 29.347 & -7.603 \\
\hline $\mathrm{o} 4_{\mathrm{NS}}$ & 128 & -0.416 & $<0.001$ & 28.632 & -6.140 \\
\hline of & 57 & -0.800 & $<0.001$ & 20.181 & -3.141 \\
\hline ug & 357 & 0.261 & $<0.001$ & 4.343 & 0.506 \\
\hline $\begin{array}{l}\text { Estuarine } \\
\text { North Sea }\end{array}$ & 3889 & -0.040 & 0.017 & 4.120 & -0.051 \\
\hline $\begin{array}{l}\text { Celtic-Biscay } \\
\text { Shelf }\end{array}$ & 115 & -0.602 & $<0.001$ & 20.402 & -2.489 \\
\hline$n p_{\mathrm{CS}}$ & 20 & -0.276 & 0.239 & - & - \\
\hline o5 & 51 & -0.212 & 0.136 & - & - \\
\hline $\mathrm{pl}$ & 44 & -0.160 & 0.299 & - & - \\
\hline Mediterranean & 394 & -0.250 & $<0.001$ & 19.620 & -1.803 \\
\hline $\mathrm{bl}$ & 2 & - & - & - & - \\
\hline do & 49 & 0.291 & 0.042 & 17.437 & 4.196 \\
\hline gr & 47 & 0.720 & $<0.001$ & 4.097 & 6.391 \\
\hline ka & 190 & -0.587 & $<0.001$ & 25.389 & -3.893 \\
\hline $\operatorname{lm}$ & 28 & -0.480 & 0.010 & 22.373 & -3.665 \\
\hline M0 & 7 & 0.254 & 0.582 & - & - \\
\hline M2 & 9 & -0.727 & 0.026 & 31.935 & -4.807 \\
\hline M3 & 6 & -0.989 & $<0.001$ & 38.864 & -7.583 \\
\hline M7 & 4 & -0.371 & 0.629 & - & - \\
\hline M8 & 8 & 0.395 & 0.333 & - & - \\
\hline oc & 1 & - & 12 & - & - \\
\hline
\end{tabular}

ers of corresponding simple linear regression models always remained low, and these models differed clearly from the $y=x$ equation. $E\left(S_{50}\right)_{0.05}$ tended to be lower in the marine North Sea than in the Celtic-Biscay Shelf and the Norwegian and Barents Seas (see Table 5 for the significance of corresponding Wilcoxon signed-rank tests).

\section{Comparisons between $\mathrm{AMBI}$ and $\mathrm{BQI}_{\mathrm{ES}}$}

AMBI and $\mathrm{BQI}_{\mathrm{ES}}$ correlated negatively in all 4 marine subareas and in the estuarine North Sea (Table 6, Figs. 6-10). However, in most cases these correlations were weak and found in only a few individual data sets.

The Celtic-Biscay Shelf was the only subarea where the use of a simple linear regression model seemed appropriate to account for the general negative relationship between AMBI and BQI $\mathrm{ES}_{\mathrm{ES}}$ (Fig. 6, Table 6). However, there was no significant negative correlation between $\mathrm{AMBI}$ and $\mathrm{BQI}_{\mathrm{ES}}$ in any individual data set within this subarea (Table 6).

A simple linear regression model did not seem appropriate to account for the relationship between $\mathrm{AMBI}$ and $\mathrm{BQI}_{\mathrm{ES}}$ in the Norwegian and Barents Seas (Fig. 7). AMBI and $\mathrm{BQI}_{\mathrm{ES}}$ correlated negatively in only 2 individual data sets (i.e. hs and $\mathrm{o} 4_{\mathrm{NB}}$, Table 6 ), and the slopes and the intercepts of the corresponding linear regression models differed significantly (ANCOVA, $\mathrm{p}<0.001$ in both cases). Moreover, low values of AMBI sometimes also corresponded to low values of $\mathrm{BQI}_{\mathrm{ES}}$ (stations in the shaded area in Fig. 7).

Negative correlations between $\mathrm{AMBI}$ and $\mathrm{BQI}_{\mathrm{ES}}$ were found in only 4 Mediterranean individual data sets (i.e. ka, lm, M2 and M3) (Fig. 8, Table 6). The

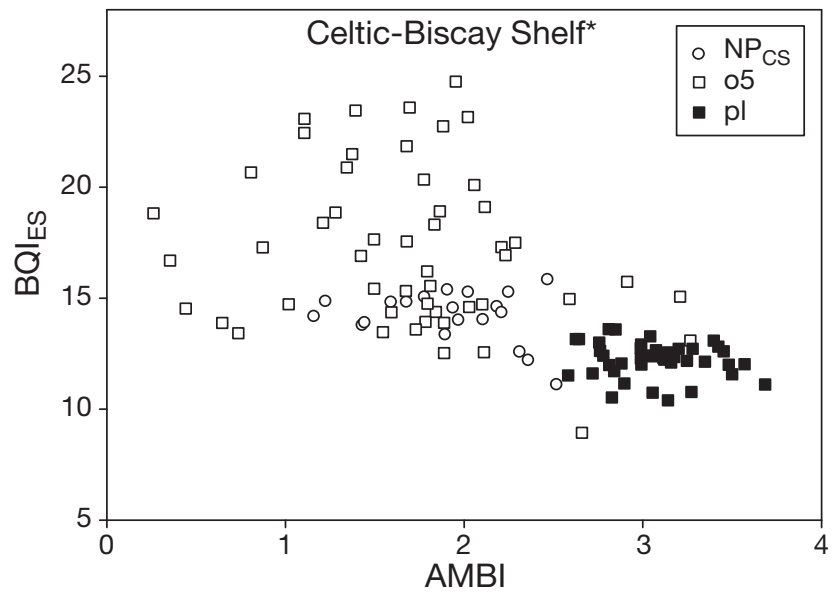

Fig. 6. Relationships between $\mathrm{AMBI}$ and $\mathrm{BQI}_{\mathrm{ES}}$ in the CelticBiscay Shelf. Symbols refer to individual data sets (see Table 1). ${ }^{*}$ Significant negative correlation (for the subarea or the individual data sets) between $\mathrm{AMBI}$ and $\mathrm{BQI} \mathrm{ES}_{\mathrm{ES}}$ 


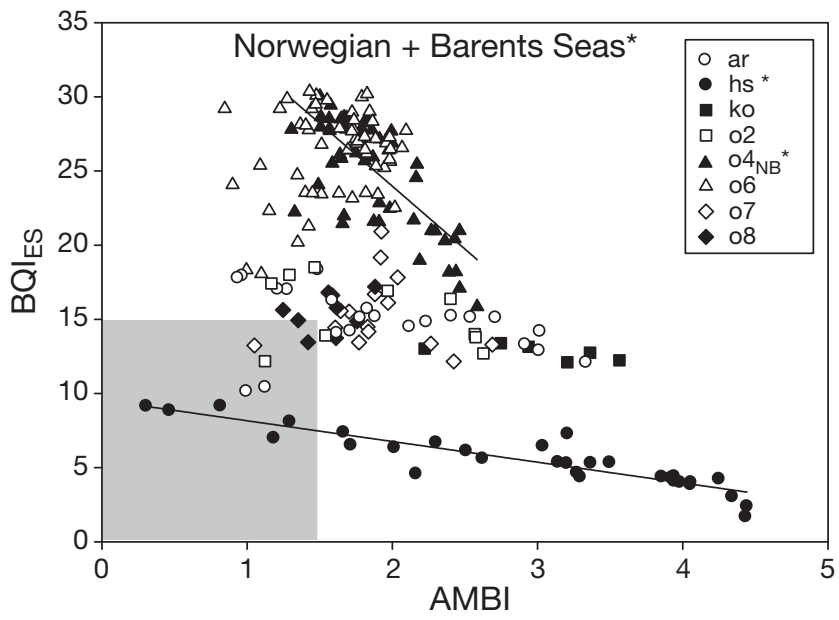

Fig. 7. Relationships between $\mathrm{AMBI}$ and $\mathrm{BQI}_{\mathrm{ES}}$ in the Norwegian and Barents Seas. Symbols refer to individual data sets (see Table 1). ${ }^{*}$ Significant $(\mathrm{p}<0.05)$ negative correlation (for the subarea or the individual data sets) between AMBI and $\mathrm{BQI}_{\mathrm{ES}}$. Shaded rectangle in the bottom left delimits stations with a low AMBI $(<1.5)$ and $\mathrm{BQI}_{\mathrm{ES}}(<15)$ (see 'ResultsComparisons between $\mathrm{AMBI}$ and $\mathrm{BQI}_{\mathrm{ES}}$ ' for details)
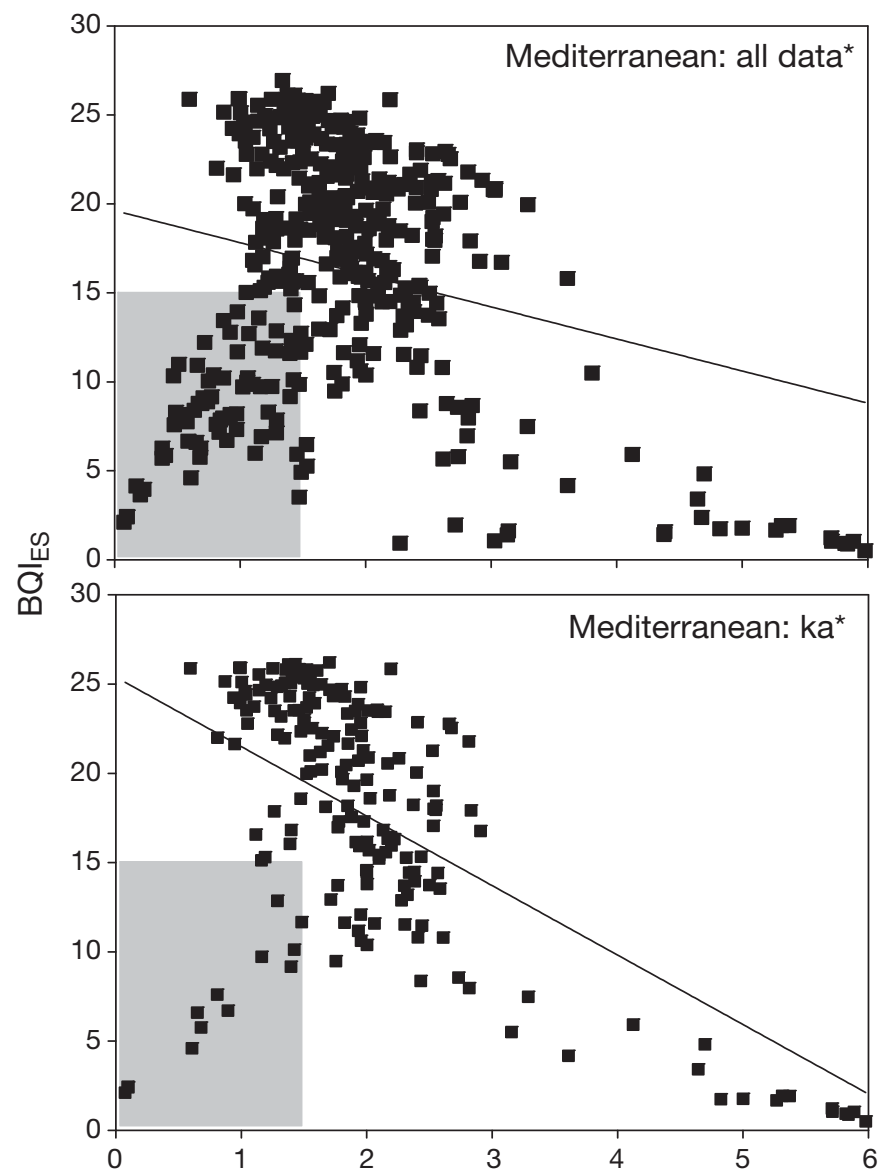

slopes of corresponding linear regression models did not differ significantly (ANCOVA, $p=0.473$ ), whereas intercepts did $(\mathrm{p}=0.027)$. Both ka and gr contained stations characterized by low values of AMBI and $\mathrm{BQI}_{\mathrm{ES}}$ (shaded area in Fig. 8, all data), which weakens the use of simple linear regression models to infer the relationships between the 2 indices for the whole Mediterranean.

In the marine North Sea (Fig. 9), high values of AMBI were also always associated with low values of $\mathrm{BQI}_{\mathrm{ES}}$. Conversely, very low values of AMBI tended to be associated with very low values of $\mathrm{BQI}_{\mathrm{ES}}$ (shaded area in Fig. 9, marine North Sea). Intermediate values of AMBI were associated with a very large range (i.e. from very high to very low) of $B Q \mathrm{EIS}_{\mathrm{ES}}$ values. The analysis of individual data sets showed the occurrence of significant negative relationships between AMBI and $\mathrm{BQI}_{\mathrm{ES}}$ in $\mathrm{o} 3$ (Fig. 9), o4 $4_{\mathrm{NS}}$ (data not shown) and 'of' (Fig. 9). The slopes and the intercepts of corresponding linear regression models differed significantly (ANCOVA, $p<0.001$ and $p=0.007$, respectively). Con-
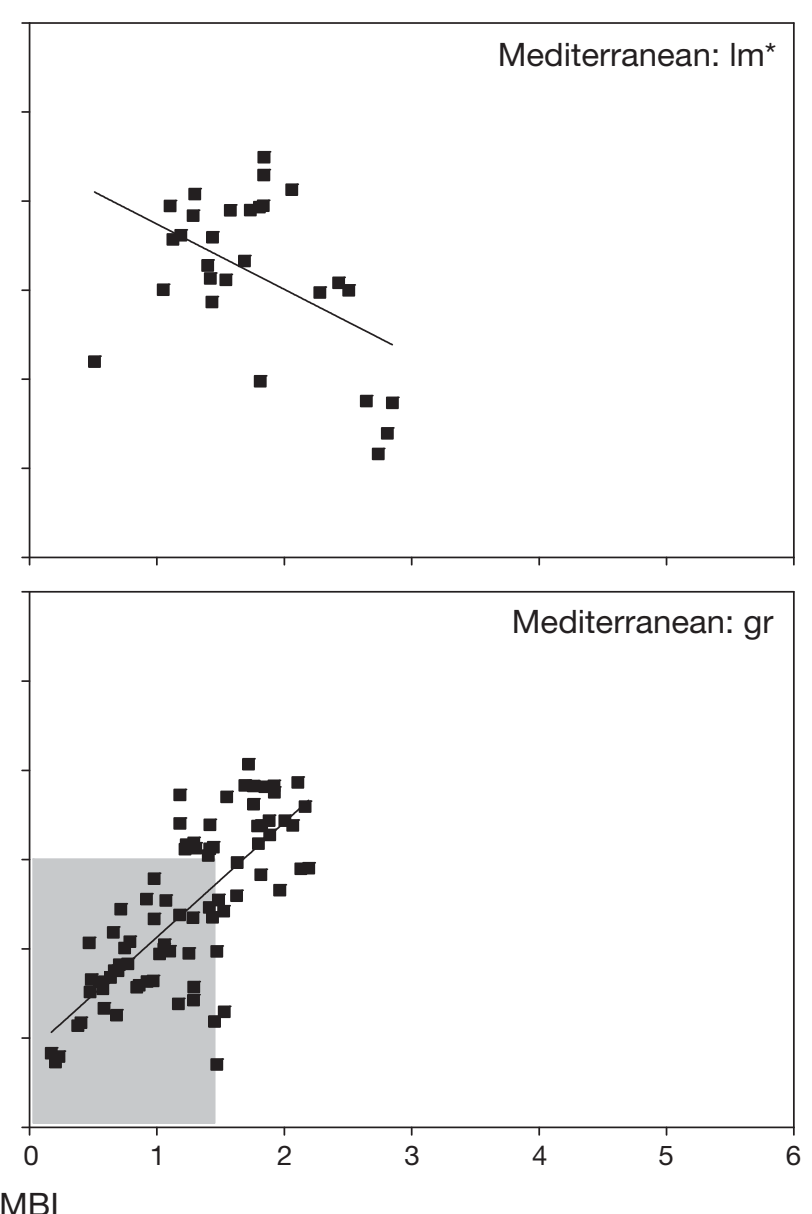

Fig. 8. Relationships between $\mathrm{AMBI}$ and $\mathrm{BQI} \mathrm{IS}_{\mathrm{ES}}$ in the Mediterranean. Data are provided for the whole Mediterranean and 3 individual data sets (see Table 1). ${ }^{*}$ Significant $(\mathrm{p}<0.05)$ negative correlation (for the subarea or the individual data sets) between $\mathrm{AMBI}$ and $\mathrm{BQI}_{\mathrm{ES}}$. Shaded rectangles in the bottom left of the Mediterranean, ka and gr graphs delimit stations with a low AMBI $(<1.5)$ and $\mathrm{BQI}_{\mathrm{ES}}(<15)$ (see 'Results-Comparisons between $\mathrm{AMBI}$ and $\mathrm{BQI}_{\mathrm{ES}}$ ' for details) 

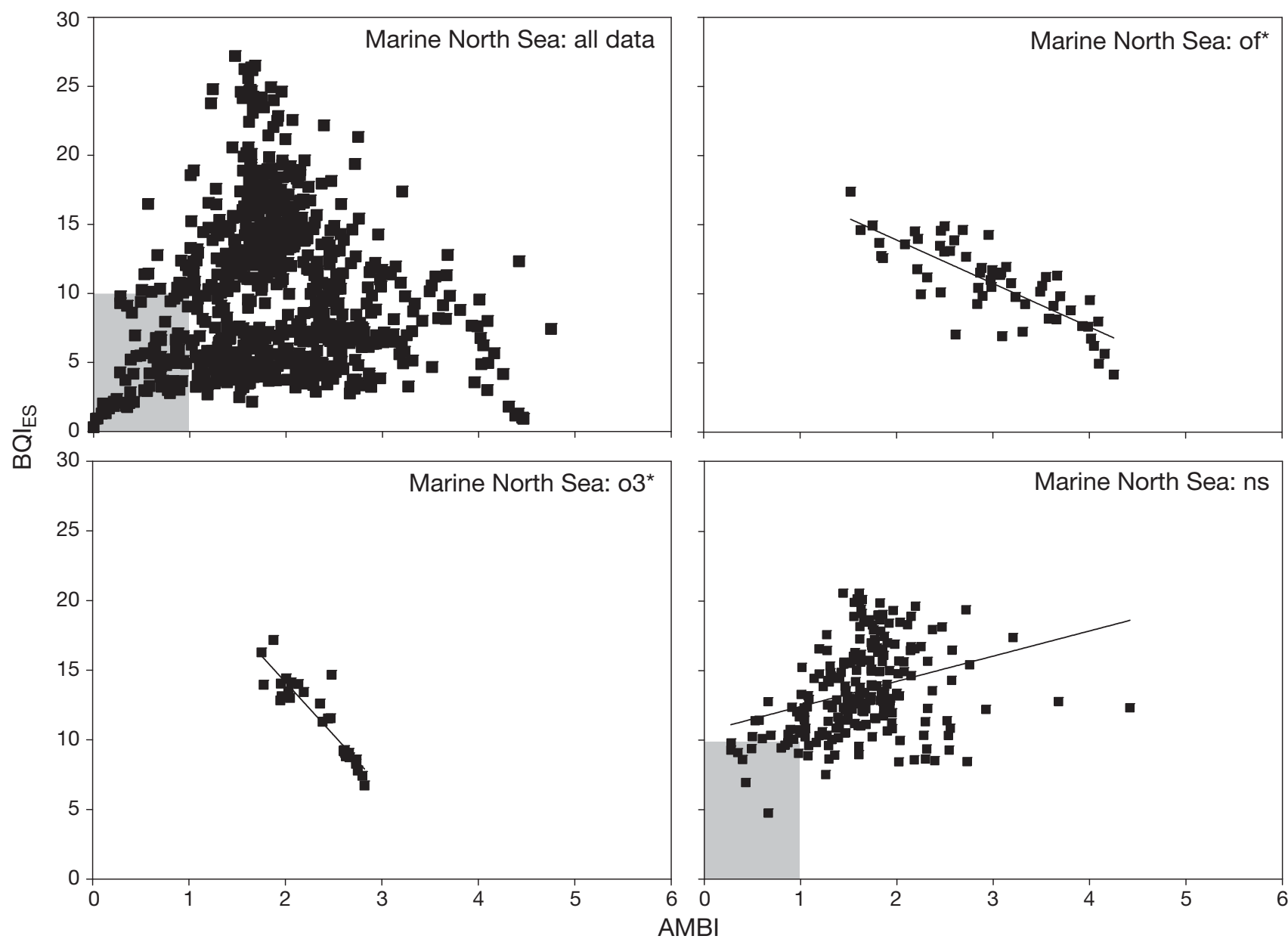

Fig. 9. Relationships between $A M B I$ and $B Q I_{E S}$ in the marine North Sea. Data are provided for the whole marine North Sea and 3 individual data sets (see Table 1). *Significant $(p<0.05)$ negative correlation (for the subarea or the individual data sets) between AMBI and BQI $\mathrm{ES}_{\mathrm{ES}}$. Shaded rectangles in the bottom left of the marine North Sea and ns graphs delimit stations with a low AMBI $(<1)$ and $\mathrm{BQI}_{\mathrm{ES}}(<10)$ (see 'Results-Comparisons between AMBI and BQI $\mathrm{ES}^{\prime}$ for details)

versely, $\mathrm{AMBI}$ and $\mathrm{BQI}_{\mathrm{ES}}$ correlated positively in $\mathrm{ns}$ (Fig. 9) and ug (data not shown). The relationship between $\mathrm{AMBI}$ and $\mathrm{BQI}_{\mathrm{ES}}$ in the estuarine North Sea (Fig. 10) was very similar to that observed in the marine North Sea.

The $\mathrm{E}\left(\mathrm{S}_{50}\right)_{0.05}$ and the AMBI EG of the most dominant species for each station characterized by low AMBI and $\mathrm{BQI}_{\mathrm{ES}}$ (shaded areas in Figs. 7-9) are listed in Table 7 . In most cases $\mathrm{E}\left(\mathrm{S}_{50}\right)_{0.05}$ were lower than expected from the AMBI EG values. This mismatch was especially clear for the most dominant species in the Norwegian and Barents Seas (Maldane sarsi), the Mediterranean (Ditrupa arietina, M. glebifex, Turritella communis and Owenia fusiformis) and the marine North Sea (Magelona mirabilis, Modiolus modiolus and Spisula subtruncata). Moreover, these species tended to be more dominant at the stations characterized by low $\mathrm{AMBI}$ and $\mathrm{BQI}_{\mathrm{ES}}$ than in the whole subareas.

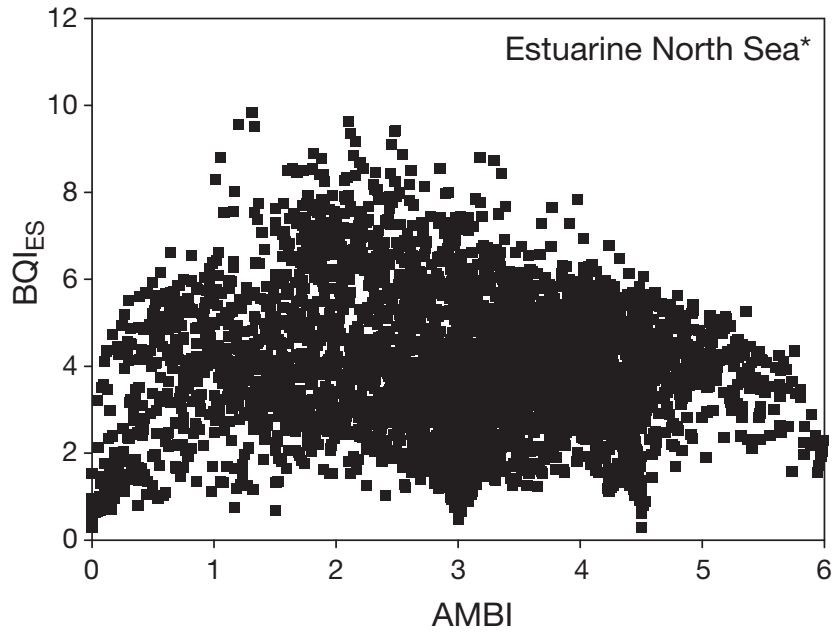

Fig. 10. Relationships between $\mathrm{AMBI}$ and $\mathrm{BQI}_{\mathrm{ES}}$ in the estuarine North Sea. ${ }^{*}$ Significant $(p<0.05)$ negative correlation (for the subarea or the individual data sets) between AMBI and $\mathrm{BQI}_{\mathrm{ES}}$ 
Table 7. Comparison of the $\mathrm{E}\left(\mathrm{S}_{50}\right)_{0.05}$ and the AMBI EG of the most dominant species at each of the stations characterized by low $\mathrm{AMBI}$ and $\mathrm{BQI}_{\mathrm{ES}}$ (shaded areas in Figs. 7-9). Species in bold are those for which (1) there is a clear mismatch between $\mathrm{E}\left(\mathrm{S}_{50}\right)_{0.05}$ and $\mathrm{AMBI} E G$, and (2) dominance is higher in the corresponding shaded area. The ranges of $\mathrm{E}\left(\mathrm{S}_{50}\right)_{0.05}$ in each subarea are given for comparison

\begin{tabular}{|c|c|c|c|c|}
\hline Species & AMBI EG & $\mathrm{E}\left(\mathrm{S}_{50}\right)_{0.05}$ & $\begin{array}{l}\text { Mean dominance in } \\
\text { shaded area }(\%)\end{array}$ & $\begin{array}{l}\text { Mean dominance in } \\
\text { whole subarea }(\%)\end{array}$ \\
\hline \multicolumn{5}{|l|}{ Norwegian and Barents Seas } \\
\hline Maldane sarsi & I & 8.5 & 29.7 & 9.7 \\
\hline Dacrydium vitreum & & 9.8 & 26.2 & 4.4 \\
\hline Lumbrineris mixochaeta & II & 5.6 & 25.4 & 16.1 \\
\hline Lumbriclymene minor & III & 13.5 & 13.9 & 1.8 \\
\hline Ophiura robusta & II & 11.5 & 9.5 & 4.2 \\
\hline Chone duneri & II & 9.8 & 7.8 & 2.9 \\
\hline Range & & $2.9-28.3$ & & \\
\hline \multicolumn{5}{|l|}{ Mediterranean } \\
\hline Ditrupa arietina & I & 3.2 & 37.8 & 17.0 \\
\hline Maldane glebifex & I & 9.1 & 23.4 & 5.6 \\
\hline Turritella communis & II & 4.4 & 16.4 & 8.9 \\
\hline Owenia fusiformis & II & 6.2 & 13.9 & 8.0 \\
\hline Nucula nucleus & I & 12.1 & 12.0 & 3.0 \\
\hline Paradoneis armata & III & 11.6 & 8.7 & 4.3 \\
\hline Spisula subtruncata & I & 4.7 & 8.6 & 7.6 \\
\hline Range & & $1.3-28.3$ & & \\
\hline \multicolumn{5}{|l|}{ Marine North Sea } \\
\hline Magelona mirabilis & I & 2.0 & 51.5 & 15.1 \\
\hline Modiolus modiolus & I & 5.9 & 18.2 & 7.2 \\
\hline Urothoe brevicornis & I & 6.1 & 12.2 & 16.5 \\
\hline Spisula subtruncata & $\mathbf{I}$ & 2.1 & 8.9 & 6.8 \\
\hline Range & & $1.0-24.1$ & & \\
\hline
\end{tabular}

\section{Comparison between ES derived from AMBI and $\mathrm{BQI}_{\mathrm{ES}}$}

The frequency distributions of the ES derived from $\mathrm{AMBI}$ and $\mathrm{BQI}_{\mathrm{ES}}$ in the 4 marine subareas are shown in Fig. 11. In all cases there were clear discrepancies. In the Celtic-Biscay Shelf and in the Mediterranean, both indices resulted in the classification of a large majority of stations as high and good. The main differences between indices were (1) the dominance of stations classified as good by AMBI versus high for $\mathrm{BQI}_{\mathrm{ES}}$ and (2) the occurrence of a larger proportion of stations classified as moderate, poor and bad by BQI $I_{E S}$ than by AMBI. Discrepancies between the indices were much larger in the Norwegian and Barents Seas and in the marine North Sea, where the majority of stations were classified as good by AMBI versus moderate, poor and bad by $\mathrm{BQI}_{\mathrm{ES}}$. In the estuarine North Sea, AMBI classified most of the stations as moderate and good versus moderate and poor for $\mathrm{BQI}_{\mathrm{ES}}$ (Fig. 12). The differences in the proportions of the stations classified as high and good versus moderate, poor and bad were 15.6, 34.8, 29.3, 51.5 and $46.1 \%$ in the Celtic-Biscay Shelf, the Norwegian and Barents Seas, the Mediterranean and the marine and estuarine North Sea, respectively.

\section{DISCUSSION}

To our knowledge, the largest comparison between EQR derived from macrozoobenthos composition in European waters was based on a database encompassing data from ca. 192 stations located in the Celtic-Biscay Shelf, the North Sea and the Kattegat (Borja et al. 2007). Three of the 4 procedures compared were based on the use of AMBI and the last one was based on the Indicator Species Index (ISI index), which is an equivalent. It was therefore not surprising that EQR computed using these procedures correlated tightly. The present study is the first to be performed at a pan-European scale (12 409 stations, including 2158 marine stations located in the CelticBiscay Shelf, the Mediterranean, the North Sea and the Norway and Barents Seas). Moreover, it compares AMBI and $\mathrm{BQI}_{\mathrm{ES}}, 2$ indices which show major differences in their way of assessing the sensitivity/tolerance level of individual species, and which have been shown to locally result in different ES assessments (Labrune et al. 2006, Dauvin et al. 2007, Zettler et al. 2007).

\section{Facilitation of the use of $\mathrm{BQI}_{\mathrm{ES}}$}

One of the major limitations to the spread of the use of $\mathrm{BQI}_{\mathrm{ES}}$ is the difficulty in deriving $\mathrm{E}\left(\mathrm{S}_{50}\right)_{0.05}$, which 

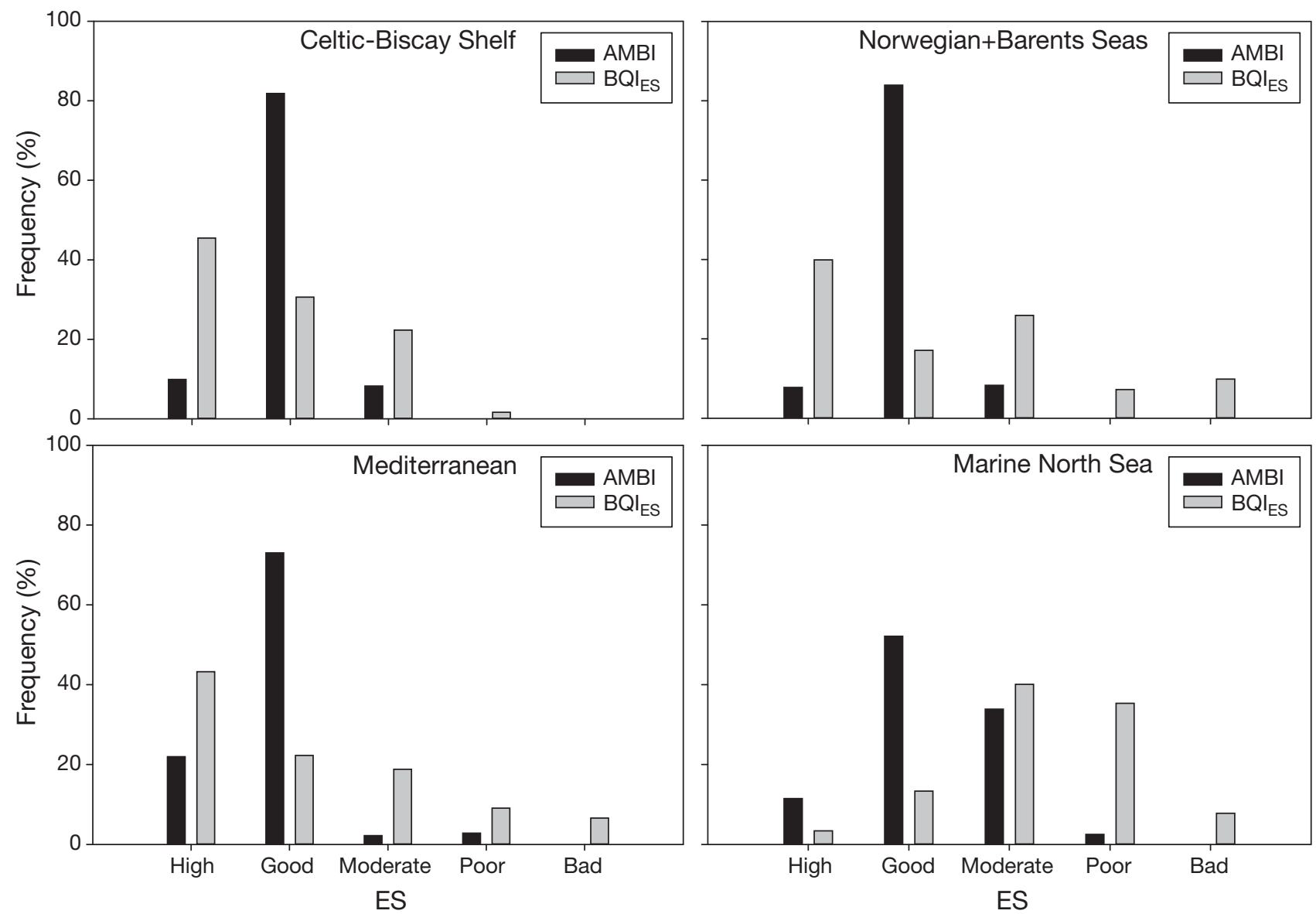

Fig. 11. Frequency distributions of ES derived from AMBI and $B \mathrm{I}_{\mathrm{ES}}$ in the 4 marine subareas: the Celtic-Biscay Shelf, the Norwegian and Barents Seas, the Mediterranean and the marine North Sea

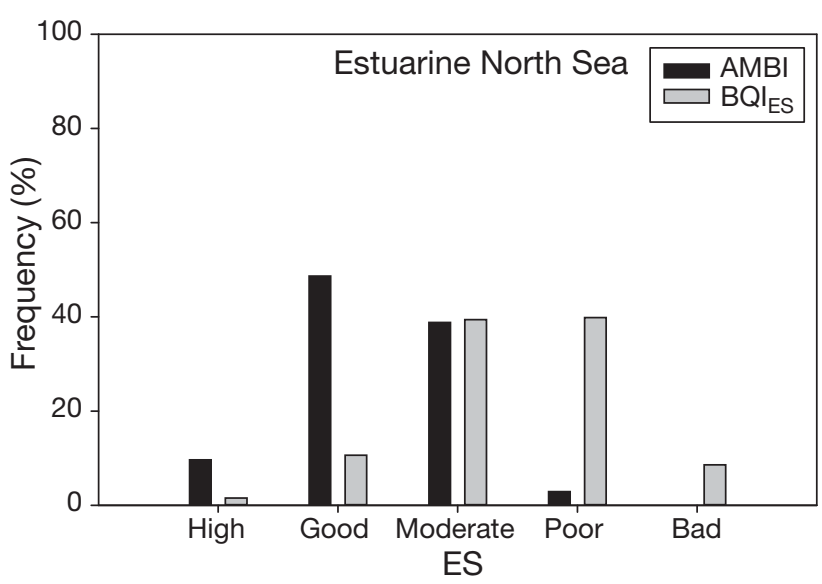

Fig. 12. Frequency distributions of ES derived from AMBI and $B Q I_{E S}$ in the estuarine North Sea

requires the species to be present in at least 20 samples (Rosenberg et al. 2004). To our knowledge, $\mathrm{E}\left(\mathrm{S}_{50}\right)_{0.05}$ lists have only been compiled for the Swedish West Coast (Rosenberg et al. 2004), the Gulf of Lions (Labrune et al. 2006), the Southern Baltic (Zettler et al. 2007), the Seine estuary (Dauvin et al. 2007) and the
Marennes Oléron and Arcachon Bays (Blanchet et al. 2008). All lists are limited regarding species numbers and are not available online except for Rosenberg et al. (2004). The present study resulted in the computation of $\mathrm{E}\left(\mathrm{S}_{50}\right)_{0.05}$ for 643 species in the whole marine indicator data set, 76 species in the Celtic-Biscay Shelf, 246 species in the Mediterranean, 337 species in the marine North Sea and 158 species in the Norwegian and Barents Seas. The proportions of species with an $\mathrm{E}\left(\mathrm{S}_{50}\right)_{0.05}$ increased with the number of stations within each subarea, which simply corresponded to the increase of the proportions of species present at more than 20 stations. In spite of the size of our data sets, the proportions of species with an $\mathrm{E}\left(\mathrm{S}_{50}\right)_{0.05}$ were always lower than for AMBI EG, which further underlines practical difficulty in computing $\mathrm{E}\left(\mathrm{S}_{50}\right)_{0.05}$ and thus $\mathrm{BQI}_{\mathrm{ES}}$. AMBI should be interpreted with caution when the proportion of non-assigned taxa is higher than $20 \%$ (Borja \& Muxika 2005). To our knowledge, no such recommendation is yet available for $\mathrm{BQI}_{\mathrm{ES}}$. Due to the strong analogy in the formula used to compute the sensitivity/tolerance terms in both $\mathrm{AMBI}$ and $\mathrm{BQI}_{\mathrm{ES}}$, this figure can nevertheless also probably be used for 
$\mathrm{BQI}_{\mathrm{ES}}$. In this sense, it is important to note that although $\mathrm{E}\left(\mathrm{S}_{50}\right)_{0.05}$ were available for $91.8 \%$ of the individuals in the whole marine indicator data set, these proportions were lower than $80 \%$ both in the Norwegian and Barents Seas and in the Celtic-Biscay Shelf.

Our $\mathrm{E}\left(\mathrm{S}_{50}\right)_{0.05}$ lists clearly could be improved and we want to stress that other data sets could be aggregated to MacroBen to refine estimates of $E\left(S_{50}\right)_{0.05}$ in each subarea. This will facilitate the use of $\mathrm{BQI}_{\mathrm{ES}}$ on small individual data sets and allow further testing of the response of $\mathrm{BQI}_{\mathrm{ES}}$ to disturbances. In this sense, the present study will contribute to further testing of $\mathrm{BQI}_{\mathrm{ES}}$ and/or to more specific comparative studies between $\mathrm{AMBI}$ and $\mathrm{BQI}_{\mathrm{ES}}$. We have also identified a list of the most dominant species in the marine indicator data set which are still either lacking an AMBI EG or an $\mathrm{E}\left(\mathrm{S}_{50}\right)_{0.05}$. Effort should now be preferentially focussed on the assessment of their sensitivity/tolerance levels to further improve the use of both indices in European waters.

\section{Comparison between AMBI EG and $\mathrm{E}\left(\mathrm{S}_{50}\right)_{0.05}$}

One would expect a strong negative correlation between AMBI EG and $\mathrm{E}\left(\mathrm{S}_{50}\right)_{0.05}$ in the case of a similar assessment of species sensitivity/tolerance levels using these 2 parameters. We indeed reported negative correlations in the whole marine indicator data set, the Norwegian and Barents Seas, and the marine and estuarine North Sea. However, the explanatory powers of the corresponding linear regression models always remained limited and we found no significant negative correlation in both the Celtic-Biscay Shelf and the Mediterranean. Our overall conclusion is that there is no good agreement between AMBI EG and $\mathrm{E}\left(\mathrm{S}_{50}\right)_{0.05}$, and in this sense our results support those already collected in more restricted areas such as the Gulf of Lions (Labrune et al. 2006) or in other subareas such as the Baltic Sea (Zettler et al. 2007).

\section{Assessment of the validity of the use of a single list of sensitivity/tolerance levels}

Bustos-Baez \& Frid (2003) showed that the response of potential indicator species to organic enrichment differed between locations, and Rosenberg et al. (2004) found that AMBI EG may vary between geographical areas. It was, therefore, interesting to compare $\mathrm{E}\left(\mathrm{S}_{50}\right)_{0.05}$ between subareas; the poor agreement probably did not result from differences in anthropogenic pressures. $\mathrm{E}\left(\mathrm{S}_{50}\right)_{0.05}$ values are mostly dependent on the $\mathrm{E}\left(\mathrm{S}_{50}\right)$ of stations with low species richness. For $\mathrm{E}\left(\mathrm{S}_{50}\right)_{0.05}$ to be comparable, it is thus not necessary for the levels of anthropogenic pressures to be strictly equivalent between subareas, but rather that a wide range from disturbed to undisturbed stations is present in all subareas. Unfortunately, there is no comprehensive information available on the level of disturbance experienced by each station in MacroBen. However, the Pearson \& Rosenberg (1978) model states that species richness decreases with disturbance. The large ranges of $\mathrm{E}\left(\mathrm{S}_{50}\right)$ recorded within each subarea therefore suggest that both disturbed and undisturbed stations were indeed present in each subarea. This was further confirmed by the large ranges of $\mathrm{ES} 5_{0.05}$ found within each marine subarea (see Table 7). Our results thus support those of Labrune et al. (2006) in showing that there are heterogeneities in $\mathrm{E}\left(\mathrm{S}_{50}\right)_{0.05}$ computed for different subareas. This does not support the use of a single list of species sensitivity/tolerance levels at the pan-European scale.

Overall, the relationships (1) between AMBI EG and $\mathrm{E}\left(\mathrm{S}_{50}\right)_{0.05}$ and (2) of $\mathrm{E}\left(\mathrm{S}_{50}\right)_{0.05}$ between subareas were rather noisy. If sensitivity/tolerance levels indeed vary between geographical areas, they also probably vary between habitats within a single geographic area, which may be partly responsible for the noise observed during the present study. Up to now (and the present study is no exception), AMBI EG and even $\mathrm{E}\left(\mathrm{S}_{50}\right)_{0.05}$ have never been assessed at the habitat level. Interesting lines for future research would thus consist of comparing $\mathrm{E}\left(\mathrm{S}_{50}\right)_{0.05}$ (1) within the same subarea but between habitats and (2) within the same habitat but between subareas. In both cases, this will require the construction of large and comprehensive databases and we suggest that this exercise should first focus on a restricted set of well-studied habitats.

\section{Unravelling the causes of discrepancies between the 2 indices}

The negative correlation between $\mathrm{AMBI}$ and $\mathrm{BQI}_{\mathrm{ES}}$ was satisfactory only in the Celtic-Biscay Shelf. Interestingly, there was no significant negative correlation between AMBI EG and E $\left(\mathrm{S}_{50}\right)_{0.05}$ in this subarea, which suggests that the agreement between the values of the 2 indices is not necessarily reliant on the general correlation between their assessments of sensitivity/tolerance levels. In all other subareas, $\mathrm{AMBI}$ and $\mathrm{BQI}_{\mathrm{ES}}$ correlated only poorly. Overall, stations with high AMBI also tended to have low $\mathrm{BQI}_{\mathrm{ES}}$. Conversely, some of the stations with low AMBI also featured low BQI $I_{E S}$. The present study shows that this mostly resulted from strong dominance by species classified as sensitive by AMBI but with a low $\mathrm{E}\left(\mathrm{S}_{50}\right)_{0.05}$. Labrune et al. (2006) reported a positive correlation between AMBI and BQI in the Gulf of Lions and attributed this result to the 
strong dominance of the serpulid polychaete Ditrupa arietina (Grémare et al. 1998, Labrune et al. 2007a), which was classified as sensitive by AMBI and had a low $\mathrm{E}\left(\mathrm{S}_{50}\right)_{0.05}$. Our results support this interpretation and generalize it to other geographical areas (e.g. the Cretan Shelf) and to other species. The present study provides the first lists of the most dominant species within each marine subarea for which there are important discrepancies between AMBI EG and $\mathrm{E}\left(\mathrm{S}_{50}\right)_{0.05}$. All were classified in AMBI EG I or II. However, some of them are known to be influenced by natural sources of disturbance such as sediment instability ( $D$. arietina, Grémare et al. 1998 and Magelona mirabilis, Rayment 2007) or climatic anomalies (Maldane glebifex, Glémarec et al. 1986) and cycles (D. arietina, Labrune et al. 2007b). These observations are indicative of the tendency of $\mathrm{E}\left(\mathrm{S}_{50}\right)_{0.05}$ to automatically classify dominant species as tolerant and its inability to differentiate between natural and anthropogenic sources of disturbance (Labrune et al. 2006, 2007b). Further autoecological studies are nevertheless clearly needed to better unravel the actual sensitivity/tolerance levels of the species highlighted in Table 7.

\section{Comparison of ES assessments derived from AMBI and $B Q I_{E S}$}

Given the discrepancies between $\mathrm{AMBI}$ and $\mathrm{BQI}_{\mathrm{ES}}$, it was not surprising that the frequency distributions of ES derived from these 2 indices differed in most subareas. In the Norwegian and Barents Seas and both the marine and estuarine North Sea, these discrepancies were also apparent when distinguishing stations with a high or good ES from those with a moderate, poor or bad ES as recommended by the WFD. BQI $I_{\mathrm{ES}}$ resulted in overall poorer ES than AMBI, which supports preliminary results in the Gulf of Lions (Labrune et al. 2006), the Southern Baltic (Zettler et al. 2007) the Bay of Seine (Dauvin et al. 2007) and to a lesser extent the North Sea (Reiss \& Kröncke 2005).

It should be underlined that all the above-mentioned studies plus the present one have used a fixed conversion scale to infer ES from AMBI. One of the characteristics of the recently introduced M-AMBI is that it is using a different conversion scale for each homogeneous habitat as does BQI $\mathrm{ES}_{\mathrm{ES}}$ (Borja et al. 2007, Muxika et al. 2007a). In both cases, this requires the existence of valid references (i.e. a single high reference in the case of $\mathrm{BQI}_{\mathrm{ES}}$, and both a bad and a high reference in the case of M-AMBI). The computation of M-AMBI was not integrated in the MacroBen tool and we did not use this procedure to infer ES during the present study.

\section{CONCLUSIONS}

$\mathrm{AMBI}$ and $\mathrm{BQI}_{\mathrm{ES}}$ both ultimately rely on species sensitivity/tolerance levels, which they respectively assess through AMBI EG and $\mathrm{E}\left(\mathrm{S}_{50}\right)_{0.05}$. We identified the most dominant species in marine European waters still lacking an AMBI EG or an $\mathrm{E}\left(\mathrm{S}_{50}\right)_{0.05}$. Our results support those of previous studies, obtained at much smaller geographical scales, in showing that AMBI EG and $\mathrm{E}\left(\mathrm{S}_{50}\right)_{0.05}$ poorly agree. They suggest that the use of a single sensitivity/tolerance list in different geographical areas (such as in AMBI EG) is not appropriate. Discrepancies between the values of the 2 indices are due to the dominance of species characterized as sensitive by AMBI and tolerant by $\mathrm{BQI}_{\mathrm{ES}}$. These species were identified and some of them are known to be influenced by natural disturbance, which highlights the tendency of $\mathrm{BQI}_{\mathrm{ES}}$ to classify dominant species as tolerant and thus to be inefficient in distinguishing anthropogenic from natural disturbances. AMBI and $\mathrm{BQI}_{\mathrm{ES}}$ thus both present weaknesses relative to the assessment of sensitivity/tolerance. Both indices have been subject to several recent refinements regarding their computation and their procedures to infer ES, which are now quite comparable. However, all these steps are posterior (and thus dependent on) a sound assessment of species sensitivity/tolerance. Changes in the scales used to convert indices to ES can only partially compensate for changes in sensitivity/tolerance levels among geographical areas and/or habitats. Preferential attention should thus now be paid to this particular issue. Future studies should focus on (1) the clarification of the sensitivity/tolerance levels of the species identified as problematic during the present study, and (2) the assessment of the relationships between AMBI EG and $\mathrm{E}\left(\mathrm{S}_{50}\right)_{0.05}$ within and between combinations of geographical areas and habitats.

Acknowledgements. This study was carried out within the framework of the EU Network of Excellence Marine Biodiversity and Ecoystem Functioning (MarBEF). We thank F. Aleffi, A. Koukouras, R. Jaskuła, A. S. Y. Mackie, P. G. Oliver, E. I. S. Rees, J. M. Węsławski, J. Wittoeck, the Norwegian Oil Industry Association, Akvaplan-niva and Det Norske Veritas for kindly providing data. We deeply thank C. Arvinitidis for organising the 2005 MarBEF Theme 1 Crete workshop where this work was initiated.

\section{LITERATURE CITED}

Bigot L, Grémare A, Amouroux JM, Frouin P (2008) Assessment of the ecological quality status of soft-bottoms in Réunion Island (Southwest Indian Ocean) using both AZTI Marine Biotic Indices. Mar Pollut Bull 56:704-722

Blanchet $\mathrm{H}$, Lavesque N, Ruellet $\mathrm{T}$, Dauvin JC and others (2008) Use of biotic indices in semi-enclosed coastal ecosystems and transitional waters habitats: implications 
for the implementation of the European Water Framework Directive. Ecol Indic 8:360-372

Borja A (2005) The European Water Framework Directive: a challenge for nearshore, coastal and continental shelf research. Cont Shelf Res 25:1768-1783

Borja A, Muxika I (2005) Guidelines for the use of AMBI (AZTI's Marine Biotic Index) in the assessment of the benthic ecological quality. Mar Pollut Bull 50:787-789

Borja A, Franco J, Pérez V (2000) A marine biotic index to establish the ecological quality of soft-bottom benthos within European estuarine and coastal environments. Mar Pollut Bull 40:1100-1114

Borja A, Muxika I, Franco J (2003) The application of a marine biotic index to different impact sources affecting soft-bottom benthic communities along European coasts. Mar Pollut Bull 46:835-845

Borja A, Franco J, Valencia V, Bald J, Muxika I, Belzunce MJ, Slaun O (2004a) Implementation of the European water framework directive from the Basque country (northern Spain): a methodological approach. Mar Pollut Bull 48:209-218

Borja A, Franco J, Muxika I (2004b) The biotic indices and the Water Framework Directive: the required consensus in the new benthic monitoring tools. Mar Pollut Bull 48:405-408

Borja A, Josefson AB, Miles A, Muxika I and others (2007) An approach to the intercalibration of benthic ecological status assessment in the North Atlantic ecoregion, according to the European Water Framework Directive. Mar Pollut Bull 55:42-52

Bustos-Baez S, Frid C (2003) Using indicator species to assess the state of macrobenthic communities. Hydrobiologia 496:299-309

Dauvin JC, Ruellet T, Desroy N, Janson AL (2007) The ecological quality status of the Bay of Seine and the Seine estuary: use of biotic indices. Mar Pollut Bull 55:241-257

Diaz RJ, Solan M, Valente RM (2004) A review of approaches for classifying benthic habitats and evaluating habitat quality. J Environ Manage 73:165-181

- Fleischer D, Grémare A, Labrune C, Rumohr H, Vanden Berghe E, Zettler ML (2007) Performance comparison of two biotic indices measuring the ecological status of water bodies in the Southern Baltic and the Gulf of Lions. Mar Pollut Bull 54:1598-1606

Glémarec M, Le Bris H, Le Guellec C (1986) Modifications des écosystèmes des vasières côtières du sud-Bretagne. Hydrobiologia 142:159-170 (In French with English abstract)

- Gomez Gesteira JL, Dauvin JC (2000) Amphipods are good bioindicators of the impact of oil spills on soft-bottom macrobenthic communities. Mar Pollut Bull 40:1017-1027

Grall J, Glémarec M (1997) Using biotic indices to estimate macrobenthic community perturbations in the Bay of Brest. Estuar Coast Shelf Sci 44(Suppl A):43-53

- Grémare A, Sardá R, Medernach L, Jordana E and others (1998) On the dramatic increase of Ditrupa arietina O.F. Müller (Annelida: Polychaeta) along both the French and Spanish Catalan coasts. Estuar Coast Shelf Sci 47:447-457

Hurlbert SH (1971) The nonconcept of species diversity: a critique and alternative parameters. Ecology 52:577-586

Labrune C, Amouroux JM, Sardá R, Dutrieux E, Thorin S Rosenberg R, Grémare A (2006) Characterization of the ecological quality of the coastal Gulf of Lions (NW Mediterranean). A comparative approach based on three biotic indices. Mar Pollut Bull 52:34-47
Labrune C, Grémare A, Amouroux JM, Sardá R, Gil J, Taboada S (2007a) Assessment of soft-bottom polychaete assemblages in the Gulf of Lions (NW Mediterranean) based on a mesoscale survey. Estuar Coast Shelf Sci 71:133-147

Labrune C, Grémare A, Guizien K, Amouroux JM (2007b) Long-term comparison of soft bottom macrobenthos in the Bay of Banyuls-sur-Mer (north-western Mediterranean Sea): a reappraisal. J Sea Res 58:125-143

Marin-Guirao L, Cesar A, Marin A, Lloret J, Vita R (2005) Establishing the ecological quality status of soft-bottom mining-impacted coastal water bodies in the scope of the Water Framework Directive. Mar Pollut Bull 50:374-387

- Muniz P, Venturini N, Pires-Vanin AMS, Tommasi LR, Borja A (2005) Testing the applicability of a marine biotic index (AMBI) to assessing the ecological quality of soft-bottom benthic communities, in the South America Atlantic region. Mar Pollut Bull 50:624-637

Muxika I, Borja A, Bonne W (2005) The suitability of the marine biotic index (AMBI) to new impact sources along European coasts. Ecol Indic 5:19-31

Muxika I, Borja A, Bald J (2007a) Using historical data, expert judgement and multivariate analysis in assessing reference conditions and benthic ecological status, according to the European Water Framework Directive. Mar Pollut Bull 55:16-29

> Muxika I, Ibaibarriaga L, Saiz JI, Borja A (2007b) Minimal sampling requirements for a precise assessment of softbottom macrobenthic communities, using AMBI. J Exp Mar Biol Ecol 349:323-333

Pearson TH, Rosenberg R (1978) Macrobenthic succession in relation to organic enrichment and pollution of the marine environment. Oceanogr Mar Biol Annu Rev 16:229-311

Rayment WJ (2007) Magelona mirabilis. A polychaete. Marine Life Information Network: Biology and Sensitivity Key Information Sub-programme. Mar Biol Assoc UK, Plymouth. Available at www.marlin.ac.uk/species/Magelonamirabilis.htm

Reiss H, Kröncke I (2005) Seasonal variability of benthic indices: An approach to test the applicability of different indices for ecosystem quality assessment. Mar Pollut Bull 50:1490-1499

> Rosenberg R, Blomqvist M, Nilsson HC, Cederwall H, Dimming A (2004) Marine quality assessment by use of benthic species-abundance distributions: a proposed new protocol within the European Union Water Framework Directive. Mar Pollut Bull 49:728-739

Salas F, Neto JM, Borja A, Marques JC (2004) Evaluation of the applicability of a marine biotic index to characterize the status of estuarine ecosystems: the case of Mondego estuary (Portugal). Ecol Indic 4:215-225

> Vanden Berghe E, Claus S, Appeltans W, Faulwetter S and others (2009) MacroBen integrated database on benthic invertebrates of European continental shelves: a tool for large-scale analysis across Europe. Mar Ecol Prog Ser 382: $225-238$

Wallin M, Wiederholm T, Johnson RK (2003) Guidance on establishing reference conditions and ecological status class boundaries for inland surface waters. Common Implementation Strategy Working Group 2.3, REFCOND, Water Framework Directive, Luxembourg

Zettler ML, Schiedek D, Bobertz B (2007) Benthic biodiversity indices versus salinity gradient in the southern Baltic Sea. Mar Pollut Bull 55:258-270 